九州大学学術情報リポジトリ

Kyushu University Institutional Repository

\title{
Synthesis and Structure-Activity Relationship of a New Series of Anti-Juvenile Hormone Agents: Alkyl 4-(2-Benzylhexyloxy)benzoates and Ethyl 4-Substituted Benzoates
}

Yoshida, Shuhe i

Laboratory of Pesticide Chemistry, Division of Plant Protection, Department of Applied Genetics and Pest Management, Faculty of Agriculture, Kyushu University

Furuta, Kenjiro

Laboratory of Pesticide Chemistry, Division of Plant Protection, Department of Applied Genetics and Pest Management, Faculty of Agriculture, Kyushu University

Shirahashi, Hiromitsu

Laboratory of Pesticide Chemistry, Division of Plant Protection, Department of Applied Genetics and Pest Management, Faculty of Agriculture, Kyushu University

Ashibe, Kiyo

Laboratory of Pesticide Chemistry, Division of Plant Protection, Department of Applied Genetics and Pest Management, Faculty of Agriculture, Kyushu University

他

https://doi.org/10.5109/14056

出版情報：九州大学大学院農学研究院紀要. 54 (1)，pp.179-184，2009-02-27. Faculty of Agriculture, Kyushu University

バージョン :

権利関係 : 


\title{
Synthesis and Structure-Activity Relationship of a New Series of Anti-Juvenile Hormone Agents: Alkyl 4-(2-Benzylhexyloxy)benzoates and Ethyl 4-Substituted Benzoates
}

\author{
Shuhei YOSHIDA ${ }^{1}$, Kenjiro FURUTA ${ }^{1}$, Hiromitsu SHIRAHASHI ${ }^{1}$, \\ Kiyo ASHIBE ${ }^{1}$, Norihiro FUJITA ${ }^{1}$, Naotaka YAMADA \\ and Eiichi KUWANO* \\ Laboratory of Pesticide Chemistry, Division of Plant Protection, Department of \\ Applied Genetics and Pest Management, Faculty of Agriculture, \\ Kyushu University, Fukuoka 812-8581, Japan \\ (Received November 5, 2008 and accepted December 5, 2008)
}

\begin{abstract}
A series of alkyl 4-(2-benzylhexyloxy)benzoates and related compounds were synthesized and investigated for their ability to induce precocious metamorphosis in larvae of Bombyx mori, a clear sign of JH deficiency in the hemolymph of early larval stages. In the alkyl 4-(2-benzylhexyloxy)benzoate series, the methyl and ethyl (KF-13) esters induced precocious metamorphosis at relatively low doses. Replacement of the ester group with an amide, alcohol, oxime, ethyl or 3,4-methylenedioxy group eliminated the activity, indicating that the ester group on the benzene ring is essential for activity. A modification was made between the two benzene rings in $\mathrm{KF}-13$. None of the compounds showed higher activity than $\mathrm{KF}-13$ at low doses. The JH activity of synthesized compounds was assayed using allatectomized 4th instar larvae of $B$. mori. The aniline analog, which showed stronger precocious metamorphosis-inducing activity than KF-13 at higher doses, had obvious JH activity. The $n$-propyl ester possessing moderate precocious metamorphosis-inducing activity did not show any JH activity. There was some correlation between the ability of compounds to cause precocious metamorphosis and their JH activity.
\end{abstract}

\section{INTRODUCTION}

Juvenile hormone ( $\mathrm{JH}$ ) is involved in a wide range of physiological events in both developing and mature insects (Riddiford, 1994). It is critical for the regulation of molting and metamorphosis. Precocious metamorphosis results from surgical removal of the corpora allata from early larval stages of the commercial silkworm, Bombyx mori (Fukuda, 1944). Similar effects have been elicited by administration of chemical compounds which act as anti-JH agents at a critical time point. Although some anti-JH agents have so far been found (Staal, 1986), their degree of activity is not sufficiently high for use as insect growth regulators (IGRs). Our studies have been concentrated on compounds inducing precocious metamorphosis, anti-JH agents (Kuwano et al., 2008), which would be expected as practical IGRs. We have recently reported that ethyl 4-(2-benzylhexyloxy) benzoate $(\mathrm{KF}-13)$ induced precocious metamorphosis in larvae of B. mori at relatively low doses (Furuta et al., 2007). Its activity was completely counteracted by the simultaneous application of methoprene, a JH agonist, showing that KF-13 caused a clear deficiency of JH titers in the larval hemolymph. From a preliminary study of the structure-activity relationship, the hexyl (KF-13) or heptyl group as an alkyl side chain was found to be optimal for high activity. The $(S)$-enantiomer of KF-13

\footnotetext{
Laboratory of Pesticide Chemistry, Division of Plant Protection, Department of Applied Genetics and Pest Management, Graduate School of Bioresource and Bioenvironmental Sciences, Kyushu University

* Corresponding author (E-mail: ekuwano@agr.kyushu-u.ac.jp)
}

was more active than the $(R)$-enantiomer at low doses, but at high doses the activity was reversed. In our continuing studies on this series of compounds, the hexyl group was fixed as an alkyl chain in the molecule, and modifications were made by replacing 4-ethoxycarbonyl group on the benzene ring with a variety of substituents, and by introducing some functional groups between the two benzene rings. In the present paper, we report the structure-activity relationships of a new series of alkyl 4-(2-benzylhexyloxy)benzoates and related compounds derived from $\mathrm{KF}-13$.

\section{MATERIALS AND METHODS}

\section{Chemicals}

The ${ }^{1} \mathrm{H}-\mathrm{NMR}$ spectra were determined with JEOL EX-400 (400 MHz) spectrometer. All melting points (mp) are uncorrected.

Compound $\mathbf{1}$ and $\mathbf{1 3}$ were prepared according to the procedure reported previously (Furuta et al., 2007 and Furuta et al., 2006). Compounds $\mathbf{1 1}$ and $\mathbf{1 2}$ were prepared according to the method described by Fujita et al. (2008). The preparation of 4-(2-benzylhexyloxy)benzoic acid derivatives and related compounds (1-4 and 6-10) is outlined in Fig. 1. 4-(2-Benzylhexyloxy)benzoic acid (III) was prepared by basic hydrolysis of $\mathbf{1}$ or 2. Compounds $\mathbf{2}, \mathbf{5}$ and $\mathbf{1 9}$ were prepared in the same manner as 1 but with use of methyl 4-hydroxybenzoate, ethyl 3-hydroxybenzoate and methyl 3-hydroxy-5-isoxazolecarboxylate, respectively, instead of ethyl 4-hydroxybenzoate.

Methyl 4-(2-benzylhexyloxy)benzoate (2)

${ }^{1} \mathrm{H}-\mathrm{NMR}\left(\mathrm{CDCl}_{3}\right) \quad \delta: 0.89(3 \mathrm{H}, \mathrm{t}, J=7.3 \mathrm{~Hz}), 1.24-1.52$ 


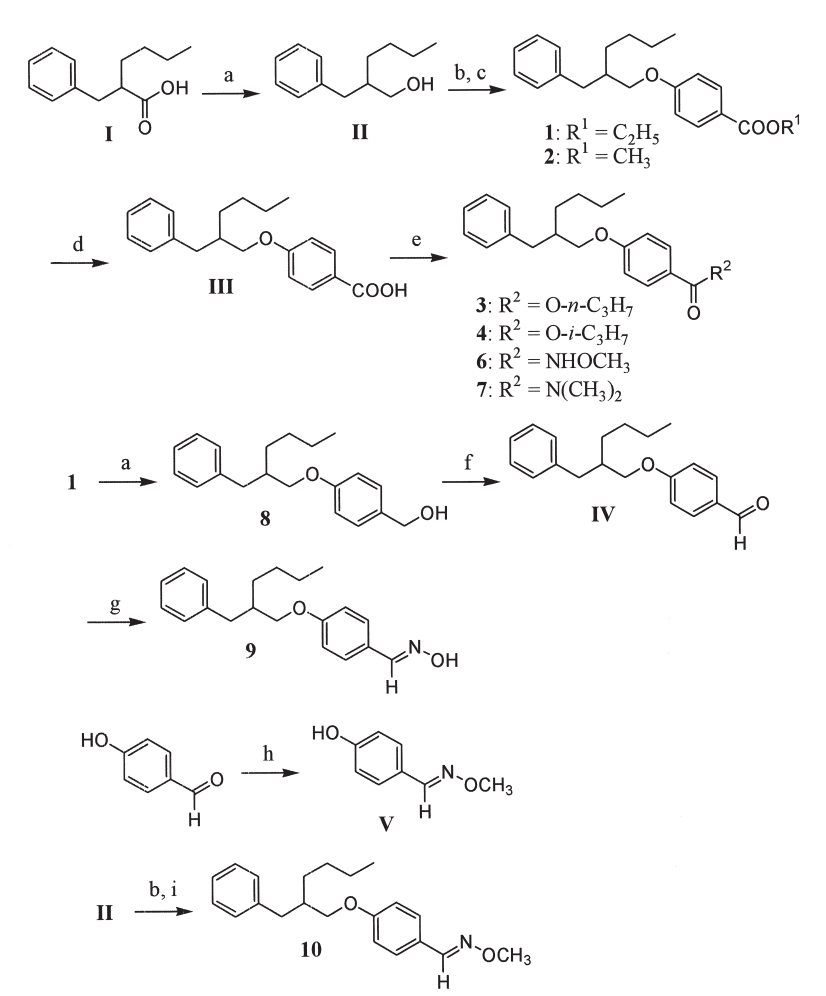

Fig. 1. Synthetic scheme for preparation of 4-(2-benzyhexyloxy) benzoic acid derivatives and related compounds (1-4 and 6-10).

(a) $\mathrm{LiAlH}_{4}$, THF; (b) $p$-toluenesulfonyl chloride, $\mathrm{N}\left(\mathrm{C}_{2} \mathrm{H}_{5}\right)_{3}$, THF; (c) ethyl 4-hydroxybenzoate or methyl 4-hydroxybenzoate, $\mathrm{K}_{2} \mathrm{CO}_{3}$, DMF; (d) $\mathrm{NaOH}$, EtOH and $\mathrm{H}_{2} \mathrm{O}$; (e) $\mathrm{NH}_{2} \mathrm{OCH}_{3} \cdot \mathrm{HCl}, \mathrm{NH}\left(\mathrm{CH}_{3}\right)_{2} \cdot \mathrm{HCl}, 1$-propanol or 2-propanol, $\mathrm{N}\left(\mathrm{C}_{2} \mathrm{H}_{5}\right)_{3}, 1-[3-($ dimethylamino)propyl]-3-ethylcarbodiimide $\cdot \mathrm{HCl}$, DMAP, $\mathrm{CH}_{2} \mathrm{Cl}_{2}$; (f) $(\mathrm{COCl})_{2}$, DMSO, $\mathrm{N}\left(\mathrm{C}_{2} \mathrm{H}_{5}\right)_{3}$, $\mathrm{CH}_{2} \mathrm{Cl}_{2} ;$ (g) $\mathrm{NH}_{2} \mathrm{OH} \cdot \mathrm{HCl}$, pyridine, $\mathrm{EtOH}$; (h) $\mathrm{NH}_{2} \mathrm{OCH}_{3} \cdot \mathrm{HCl}$, pyridine, EtOH; (i) compound $\mathbf{V}, \mathrm{K}_{2} \mathrm{CO}_{3}$, DMF.

(6H, m), 2.07-2.11 (1H, m), $2.75(2 \mathrm{H}, \mathrm{d}, J=6.8 \mathrm{~Hz}), 3.83$ $(2 \mathrm{H}, \mathrm{d}, J=5.4 \mathrm{~Hz}), 3.88(3 \mathrm{H}, \mathrm{s}), 6.87(2 \mathrm{H}, \mathrm{d}, J=8.8 \mathrm{~Hz})$, $7.14-7.20$ (3H, m), 7.24-7.29 (2H, m), 7.96 (2H, d, $J=8.8 \mathrm{~Hz})$

Ethyl 3-(2-benzylhexyloxy)benzoate (5)

${ }^{1} \mathrm{H}-\mathrm{NMR}\left(\mathrm{CDCl}_{3}\right) \delta: 0.90(3 \mathrm{H}, \mathrm{t}, J=6.8 \mathrm{~Hz}), 1.24-1.53$ (6H, m), 1.39 (3H (overlapped), t, $J=7.3 \mathrm{~Hz}$ ), 2.04-2.09 $(1 \mathrm{H}, \mathrm{m}), 2.71-2.82(2 \mathrm{H}, \mathrm{m}), 3.83(2 \mathrm{H}, \mathrm{d}, J=5.4 \mathrm{~Hz}), 4.35$ $(2 \mathrm{H}, \mathrm{q}, J=7.3 \mathrm{~Hz}), 7.06(1 \mathrm{H}, \mathrm{dd}, J=2.0$ and $7.8 \mathrm{~Hz})$, 7.15-7.24 (3H, m), 7.28-7.34 (3H, m), 7.52-7.53 (1H, m), $7.62(1 \mathrm{H}, \mathrm{d}, J=7.8 \mathrm{~Hz})$.

Methyl 3-(2-benzylhexyloxy)-5-isoxazolecarboxylate (19)

${ }^{1} \mathrm{H}-\mathrm{NMR}\left(\mathrm{CDCl}_{3}\right) \quad \delta: 0.88(3 \mathrm{H}, \mathrm{t}, J=6.8 \mathrm{~Hz}), 1.26-1.45$ (6H, m), 2.08-2.11 (1H, m), 2.70-2.73 (1H, m), 3.95 $(3 \mathrm{H}, \mathrm{s}), 4.15(2 \mathrm{H}, \mathrm{dd}, J=2.0$ and $5.4 \mathrm{~Hz}), 6.54(1 \mathrm{H}, \mathrm{s})$, 7.14-7.21 (3H, m), 7.25-7.29 (2H, m).

N-Methoxy-4-(2-benzylhexyloxy)benzamide (6)

A mixture of $O$-methylhydroxylamine hydrochloride $(0.13 \mathrm{~g}, 1.6 \mathrm{mmol})$ and triethylamine $(0.26 \mathrm{~g}, 2.6 \mathrm{mmol})$ in $10 \mathrm{ml}$ of dichloromethane was stirred for $1 \mathrm{hr}$ at room temperature. To the mixture was added compound III (0.4 g, $\quad 1.3 \mathrm{mmol}), \quad 4-(N, N$-dimethylamino)pyridine (DMAP, $0.02 \mathrm{~g}, 0.16 \mathrm{mmol})$ and $1-[3-($ dimethylamino $)$ propyl]-3-ethylcarbodiimide hydrochloride (0.35 g, $1.8 \mathrm{mmol}$ ) at $0{ }^{\circ} \mathrm{C}$. After stirring overnight at room temperature, a $2 \mathrm{M}$ aqueous solution of $\mathrm{HCl}(5 \mathrm{ml})$ was added to the mixture and the product was extracted with ethyl acetate. The ethyl acetate solution was washed with brine, dried over $\mathrm{Na}_{2} \mathrm{SO}_{4}$, and concentrated. The residue was purified by column chromatography on silica gel eluting with hexane and ethyl acetate (1:1) to afford $0.34 \mathrm{~g}(78 \%)$ of $\mathbf{6}$ as a colorless oil. ${ }^{1} \mathrm{H}-\mathrm{NMR}\left(\mathrm{CDCl}_{3}\right) \delta$ : $0.89(3 \mathrm{H}, \mathrm{t}, J=6.8 \mathrm{~Hz}), 1.24-1.52(6 \mathrm{H}, \mathrm{m}), 2.06-2.09(1 \mathrm{H}$, m), $2.75(2 \mathrm{H}, \mathrm{d}, J=6.8 \mathrm{~Hz}), 3.82(2 \mathrm{H}, \mathrm{d}, J=5.4 \mathrm{~Hz}), 3.87$ $(3 \mathrm{H}, \mathrm{s}), 6.87(2 \mathrm{H}, \mathrm{d}, J=8.8 \mathrm{~Hz}), 7.14-7.20$ (3H, m), 7.24-7.28 (2H, m), 7.68 (2H, d, J=8.8 Hz), 8.58 (1H, br s).

Compound $\mathbf{7}$ was prepared in the same manner as compound $\mathbf{6}$ with use of dimethylamine hydrochloride instead of $O$-methylhydroxylamine hydrochloride.

N,N-Dimethyl-4-(2-benzylhexyloxy)benzamide (7)

${ }^{1} \mathrm{H}-\mathrm{NMR}\left(\mathrm{CDCl}_{3}\right) \delta: 0.89(3 \mathrm{H}, \mathrm{t}, J=7.3 \mathrm{~Hz}), 1.24-1.53$ $(6 \mathrm{H}, \mathrm{m}), 2.04-2.10(1 \mathrm{H}, \mathrm{m}), 2.72-2.78(2 \mathrm{H}, \mathrm{m}), 3.06$ $(6 \mathrm{H}, \mathrm{s}), 3.80(2 \mathrm{H}, \mathrm{d}, J=4.9 \mathrm{~Hz}), 6.85(2 \mathrm{H}, \mathrm{d}, J=8.3 \mathrm{~Hz})$, 7.15-7.20 (3H, m), 7.25-7.36 (2H, m), 7.37 (2H, d, $J=8.3 \mathrm{~Hz})$.

In a similar manner, compounds $\mathbf{3}$ and $\mathbf{4}$ were prepared by reacting III with 1-propanol and 2-propanol, respectively.

n-Propyl 4-(2-benzylhexyloxy)benzoate (3)

${ }^{1} \mathrm{H}-\mathrm{NMR}\left(\mathrm{CDCl}_{3}\right) \delta: 0.89(3 \mathrm{H}, \mathrm{t}, J=7.3 \mathrm{~Hz}), 1.02(3 \mathrm{H}$, $\mathrm{t}, J=7.3 \mathrm{~Hz}), 1.20-1.55(6 \mathrm{H}, \mathrm{m}), 1.70-1.85(2 \mathrm{H}, \mathrm{m})$, 2.02-2.12 (1H, m), $2.75(2 \mathrm{H}, \mathrm{d}, J=7.3 \mathrm{~Hz}), 3.83(2 \mathrm{H}, \mathrm{d}$, $J=5.3 \mathrm{~Hz}), 4.24(2 \mathrm{H}, \mathrm{t}, J=6.8 \mathrm{~Hz}), 6.87(2 \mathrm{H}, \mathrm{d}, J=8.8 \mathrm{~Hz})$, $7.10-7.30$ (5H, m), $7.96(2 \mathrm{H}, \mathrm{d}, J=8.8 \mathrm{~Hz})$.

Isopropyl 4-(2-benzylhexyloxy)benzoate (4)

${ }^{1} \mathrm{H}-\mathrm{NMR}(\mathrm{CDCl} 3) \quad \delta: 0.89(3 \mathrm{H}, \mathrm{t}, J=7.3 \mathrm{~Hz}), 1.35$ $(6 \mathrm{H}, \mathrm{d}, J=6.3 \mathrm{~Hz}), 1.30-1.60(6 \mathrm{H}, \mathrm{m}), 2.04-2.10(1 \mathrm{H}, \mathrm{m})$, $2.75(2 \mathrm{H}, \mathrm{d}, J=7.3 \mathrm{~Hz}), 3.83(2 \mathrm{H}, \mathrm{d}, J=6.4 \mathrm{~Hz}), 5.19-5.23$ ( $1 \mathrm{H}, \mathrm{m}), 6.86(2 \mathrm{H}, \mathrm{d}, J=8.8 \mathrm{~Hz}), 7.14-7.27$ (5H, m), 7.96 $(2 \mathrm{H}, \mathrm{d}, J=8.8 \mathrm{~Hz})$.

\section{4-(2-Benzylhexyloxy)benzyl alcohol (8)}

A mixture of compound $\mathbf{1}(1.0 \mathrm{~g}, 2.9 \mathrm{mmol})$ and lithium aluminum hydride $(0.11 \mathrm{~g}, 2.9 \mathrm{mmol})$ in $15 \mathrm{ml}$ of tetrahydrofuran (THF) was stirred for $2 \mathrm{hr}$ at room temperature. The reaction mixture was quenched with saturated $\mathrm{NH}_{4} \mathrm{Cl}$ solution at $0{ }^{\circ} \mathrm{C}$. After removal of the solvent under reduced pressure, the product was extracted with ethyl acetate. The ethyl acetate solution was washed with brine and dried over $\mathrm{Na}_{2} \mathrm{SO}_{4}$. After concentration under reduced pressure, the residue was chromatographed on silica gel by elution with hexane and ethyl acetate (5:1) to afford $0.85 \mathrm{~g}(97 \%)$ of $\mathbf{8}$ as a colorless oil. ${ }^{1} \mathrm{H}-\mathrm{NMR}\left(\mathrm{CDCl}_{3}\right) \delta: 0.89(3 \mathrm{H}, \mathrm{t}, J=6.8 \mathrm{~Hz}), 1.26-1.53$ $(6 \mathrm{H}, \mathrm{m}), 2.04-2.08(1 \mathrm{H}, \mathrm{m}), 3.78(2 \mathrm{H}, \mathrm{d}, J=5.6 \mathrm{~Hz}), 4.61$ $(2 \mathrm{H}, \mathrm{d}, J=5.9 \mathrm{~Hz}), 6.85(2 \mathrm{H}, \mathrm{d}, J=8.3 \mathrm{~Hz}), 7.15-7.17(3 \mathrm{H}$, m), 7.19-7.24 (2H, m), 7.27 (2H, d, $J=8.3 \mathrm{~Hz})$.

4-(2-Benzylhexyloxy)benzaldehyde (IV)

To a solution of oxalyl chloride $(0.43 \mathrm{~g}, 3.4 \mathrm{mmol})$ in $10 \mathrm{ml}$ of dichloromethane at $-78^{\circ} \mathrm{C}$ was added dimethylsulfoxide ( $0.39 \mathrm{~g}, 5.0 \mathrm{mmol}$ ) and the solution was stirred for $1 \mathrm{hr}$. To the mixture was added a solution of compound $5(0.5 \mathrm{~g}, 1.7 \mathrm{mmol})$ in $5 \mathrm{ml}$ of dichloromethane. After stirring for $1.5 \mathrm{hr}$ at $-78^{\circ} \mathrm{C}$, triethylamine $(1.2 \mathrm{~g}$, 
$11.8 \mathrm{mmol}$ ) was added to the mixture. The mixture was stirred for $0.5 \mathrm{hr}$ for $-78^{\circ} \mathrm{C}$ and then for $0.5 \mathrm{hr}$ at $0{ }^{\circ} \mathrm{C}$. The mixture was quenched by adding saturated $\mathrm{NH}_{4} \mathrm{Cl}$ solution at $0{ }^{\circ} \mathrm{C}$. The product was extracted with ethyl acetate. The ethyl acetate solution was washed with brine, dried over $\mathrm{Na}_{2} \mathrm{SO}_{4}$, and concentrated. The residue was purified by column chromatography on silica gel eluting with hexane and ethyl acetate (5:1) to afford $0.56 \mathrm{~g}$ (94\%) of IV as a colorless oil. ${ }^{1} \mathrm{H}-\mathrm{NMR}\left(\mathrm{CDCl}_{3}\right) \delta: 0.89$ ( $3 \mathrm{H}, \mathrm{t}, J=6.8 \mathrm{~Hz}), 1.24-1.55$ (6H, m), 2.04-2.13 (1H, m), $2.75(2 \mathrm{H}, \mathrm{d}, J=6.8 \mathrm{~Hz}), 3.86(2 \mathrm{H}, \mathrm{d}, J=5.4 \mathrm{~Hz}), 7.95(2 \mathrm{H}$, d, $J=8.3 \mathrm{~Hz}$ ), 7.14-7.21 (3H, m), 7.24-7.27 (2H, m), 7.81 $(2 \mathrm{H}, \mathrm{d}, J=8.3 \mathrm{~Hz}), 9.88(1 \mathrm{H}, \mathrm{s})$.

4-(2-Benzylhexyloxy)benzaldehyde oxime (9)

To a solution of compound IV $(0.5 \mathrm{~g}, 1.7 \mathrm{mmol})$ in pyridine and ethanol was added hydroxylamine hydrochloride $(0.13 \mathrm{~g}, 1.9 \mathrm{mmol})$. After stirring for $12 \mathrm{hr}$ at room temperature, the mixture was concentrated under reduced pressure. To the residue was added $2 \mathrm{M} \mathrm{HCl}$ solution and the product was extracted with ethyl acetate. The ethyl acetate solution was washed with brine, dried over $\mathrm{Na}_{2} \mathrm{SO}_{4}$, and concentrated. The residue was purified by column chromatography on silica gel eluting with hexane and ethyl acetate (4:1) to afford $0.33 \mathrm{~g}(63 \%)$ of $\mathbf{9}$ as a colorless oil. ${ }^{1} \mathrm{H}-\mathrm{NMR}\left(\mathrm{CDCl}_{3}\right) \delta: 0.89(3 \mathrm{H}, \mathrm{t}$, $J=6.8 \mathrm{~Hz}), \quad 1.24-1.53$ (6H, m), 2.06-2.10 (1H, m), 2.74-2.76 (2H, m), $3.81(2 \mathrm{H}, \mathrm{d}, J=5.4 \mathrm{~Hz}), 6.86(2 \mathrm{H}, \mathrm{d}$, $J=8.8 \mathrm{~Hz}$ ), 7.15-7.20 (3H, m), 7.24-7.28 (2H, m), 7.41 $(2 \mathrm{H}, \mathrm{d}, J=8.8 \mathrm{~Hz}), 8.08(1 \mathrm{H}, \mathrm{s})$.

4-Hydroxybenzaldehyde O-methyloxime (V)

A mixture of 4-hydroxybenzaldehyde ( $0.5 \mathrm{~g}$, $4.1 \mathrm{mmol}$ ) and $O$-methylhydroxylamine hydrochloride $(0.38 \mathrm{~g}, 4.6 \mathrm{mmol})$ in pyridine $(5 \mathrm{ml})$ and ethanol $(5 \mathrm{ml})$ was stirred for $12 \mathrm{hr}$ at room temperature. After removal of the solvent, the product was extracted with ethyl acetate. The organic layer was washed with water and brine, dried over $\mathrm{Na}_{2} \mathrm{SO}_{4}$, and concentrated. The residue was purified by column chromatography on silica gel eluting with hexane and ethyl acetate (2:1) to afford $0.59 \mathrm{~g}$ (95\%) of $\mathbf{V}$ as a colorless oil. ${ }^{1} \mathrm{H}-\mathrm{NMR}\left(\mathrm{CDCl}_{3}\right) \quad \delta: 3.95$ (3H. s), 5.01 (1H, br s), $6.83(2 \mathrm{H}, \mathrm{dd}, J=2.0$ and $6.4 \mathrm{~Hz})$, 7.48 (2H, dd, $J=2.0$ and $6.4 \mathrm{~Hz}), 8.01(1 \mathrm{H}, \mathrm{s})$.

4-(2-Benzylhexyloxy)benzaldehyde O-methyloxime (10)

A solution of compound II $(0.5 \mathrm{~g}, 2.6 \mathrm{mmol})$, triethylamine (0.29 g, $2.9 \mathrm{mmol})$ and $p$-toluenesulfonyl chloride $(0.55 \mathrm{~g}, 2.9 \mathrm{mmol})$ in $15 \mathrm{ml}$ of dichloromethane was stirred for $36 \mathrm{hr}$ at room temperature. After removal of the solvent, the product was extracted with ethyl acetate. The organic layer was washed with brine, and dried over $\mathrm{Na}_{2} \mathrm{SO}_{4}$. Concentration of the solvent gave crude 2-benzylhexyl $p$-toluenesulfonate. A mixture of the above $p$-toluenesulfonate, compound $\mathbf{V}(0.43 \mathrm{~g}, 2.8 \mathrm{mmol})$ and potassium carbonate $(0.43 \mathrm{~g}, 3.1 \mathrm{mmol})$ in $25 \mathrm{ml}$ of dimethylformamide (DMF) was heated at $90-100{ }^{\circ} \mathrm{C}$ for $6 \mathrm{hr}$. To the mixture was added $30 \mathrm{ml}$ of water and the product was extracted with ethyl acetate. The ethyl acetate solution was washed with $2 \mathrm{M} \mathrm{NaOH}$ solution, water, and brine, dried over $\mathrm{Na}_{2} \mathrm{SO}_{4}$, and concentrated. The residue was purified by column chromatography on silica

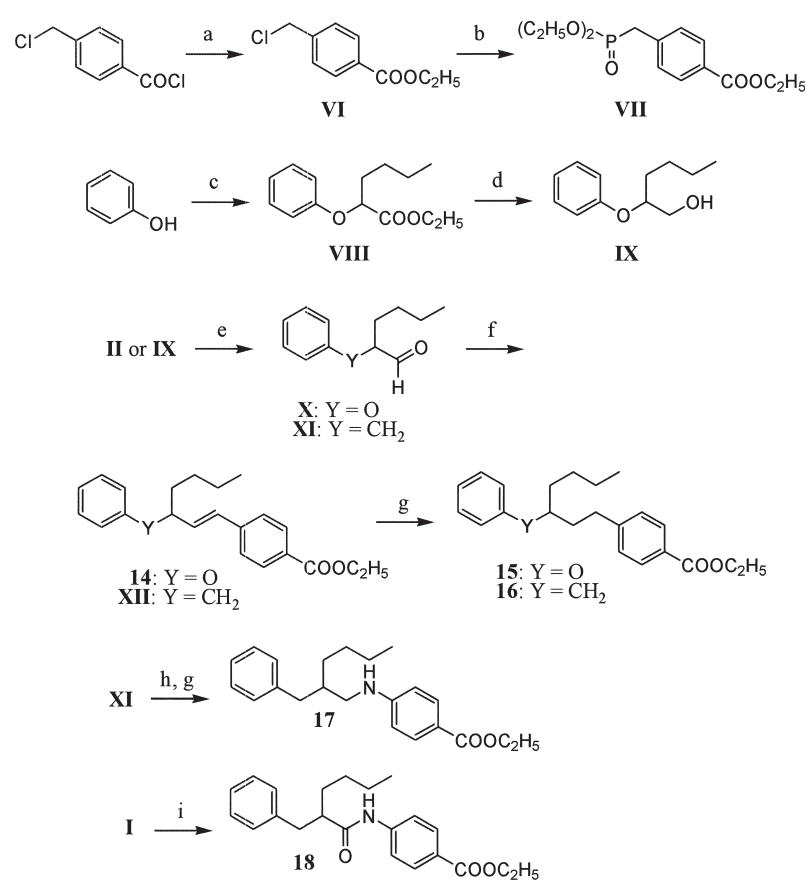

Fig. 2. Synthetic scheme for preparation of ethyl 4-substitued benzoates 14-18.

(a) 4-chloromethylbenzoyl chloride, $\mathrm{N}\left(\mathrm{C}_{2} \mathrm{H}_{5}\right)_{3}$, EtOH; (b) triethyl phosphite; (c) ethyl 2-bromohexanoate, $\mathrm{K}_{2} \mathrm{CO}_{3}$,

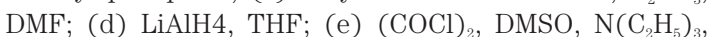
$\mathrm{CH}_{2} \mathrm{Cl}_{2}$; (f) compound VII, NaH, THF; (g) $\mathrm{Pd} / \mathrm{C}, \mathrm{H}_{2}, \mathrm{MeOH}$; (h) ethyl 4-aminobenzoate, $\mathrm{MgSO}_{4}, \mathrm{EtOH}$; (i) ethyl 4-aminobenzoate, DMAP, 1-[3-(dimethylamino)propyl]3-ethylcarbodiimide. $\mathrm{HCl}, \mathrm{CH}_{2} \mathrm{Cl}_{2}$.

gel eluting with hexane and ethyl acetate (15:1) to afford $0.59 \mathrm{~g}(69 \%)$ of $\mathbf{1 0}$ as a colorless oil. ${ }^{1} \mathrm{H}-\mathrm{NMR}$ (CDCl3) $\delta: 0.89(3 \mathrm{H}, \mathrm{t}, J=6.8 \mathrm{~Hz}), 1.26-1.50(6 \mathrm{H}, \mathrm{m}), 2.05-2.08$ $(1 \mathrm{H}, \mathrm{m}), 2.73-2.76(2 \mathrm{H}, \mathrm{m}), 3.80(2 \mathrm{H}, \mathrm{d}, J=4.9 \mathrm{~Hz}), 3.95$ $(3 \mathrm{H}, \mathrm{s}), 6.85(2 \mathrm{H}, \mathrm{d}, J=8.8 \mathrm{~Hz}), 7.14-7.20(3 \mathrm{H}, \mathrm{m})$, 7.26-7.28 (2H, m), 7.49 (2H, d, J=8.8 Hz), 8.01 (1H, s).

Ethyl 4-substituted benzoates (14-18) were synthesized as shown in Fig. 2.

Ethyl 4-chloromethylbenzoate (VI)

To a solution of 4-chloromethylbenzoyl chloride $(0.6 \mathrm{~g}, 3.2 \mathrm{mmol})$ in $30 \mathrm{ml}$ of ethanol was added triethylamine $(0.32 \mathrm{~g}, 3.2 \mathrm{mmol})$ at $0{ }^{\circ} \mathrm{C}$ and the mixture was stirred for $12 \mathrm{hr}$ at room temperature. After removal of the solvent, the product was extracted with ethyl acetate. The ethyl acetate solution was washed with water and brine, dried over $\mathrm{Na}_{2} \mathrm{SO}_{4}$, and concentrated. The residue was purified by column chromatography on silica gel eluting with hexane and ethyl acetate $(5: 1)$ to afford $0.62 \mathrm{~g}(98 \%)$ of $\mathbf{V I}$ as a colorless oil. ${ }^{1} \mathrm{H}-\mathrm{NMR}\left(\mathrm{CDCl}_{3}\right) \delta$ : $1.40(3 \mathrm{H}, \mathrm{t}, J=7.3 \mathrm{~Hz}), 4.38(2 \mathrm{H}, \mathrm{q}, J=7.3 \mathrm{~Hz}), 4.62(2 \mathrm{H}$, s), $7.46(2 \mathrm{H}, \mathrm{d}, J=8.3 \mathrm{~Hz}), 8.04(2 \mathrm{H}, \mathrm{d}, J=8.3 \mathrm{~Hz})$.

Diethyl 4-(ethoxycarbonyl)benzylphosphonate (VII)

A mixture of compound VI $(0.46 \mathrm{~g}, 2.8 \mathrm{mmol})$ and triethyl phosphate $(0.5 \mathrm{~g}, 2.5 \mathrm{mmol})$ was heated for $6 \mathrm{hr}$. The crude product was purified by silica gel column chromatography eluting with hexane and ethyl acetate (5:1) to give $0.38 \mathrm{~g}(50 \%)$ of $\mathbf{V I I}$ as a yellow oil. ${ }^{1} \mathrm{H}-\mathrm{NMR}$ 
$\left(\mathrm{CDCl}_{3}\right) \delta: 1.25(6 \mathrm{H}, \mathrm{t}, J=7.3 \mathrm{~Hz}), 1.39(3 \mathrm{H}, \mathrm{t}, J=7.3 \mathrm{~Hz})$, $3.20(2 \mathrm{H}, \mathrm{d}, J=22 \mathrm{~Hz}), 4.00-4.04(4 \mathrm{H}, \mathrm{m}), 4.37(2 \mathrm{H}, \mathrm{q}$, $J=7.3 \mathrm{~Hz}), 7.37(2 \mathrm{H}, \mathrm{d}, J=8.3 \mathrm{~Hz}), 7.99(2 \mathrm{H}, \mathrm{d}, J=8.3 \mathrm{~Hz})$. Ethyl 2-phenoxyhexanoate (VIII)

A mixture of phenol $(0.5 \mathrm{~g}, 5.3 \mathrm{mmol})$ and potassium carbonate $(0.88 \mathrm{~g}, 6.4 \mathrm{mmol})$ in $15 \mathrm{ml}$ of DMF was stirred for $0.5 \mathrm{hr}$ at room temperature. To the mixture was added ethyl 2-bromohexanoate ( $0.81 \mathrm{~g}, 3.6 \mathrm{mmol})$. After stirring for $12 \mathrm{hr}$ at room temperature, the product was poured into water and the product was extracted with ethyl acetate. The ethyl acetate solution was washed with brine, dried over $\mathrm{Na}_{2} \mathrm{SO}_{4}$, and concentrated. The residue was purified by column chromatography on silica gel eluting with hexane and ethyl acetate (10:1) to afford $0.6 \mathrm{~g}(48 \%)$ of VIII as a yellow oil. ${ }^{1} \mathrm{H}-\mathrm{NMR}\left(\mathrm{CDCl}_{3}\right) \quad \delta$ : $0.93(3 \mathrm{H}, \mathrm{t}, J=7.3 \mathrm{~Hz}), 1.24(3 \mathrm{H}, \mathrm{t}, J=7.3 \mathrm{~Hz}), 1.34-1.57$ $(4 \mathrm{H}, \mathrm{m}), 1.90-1.98(2 \mathrm{H}, \mathrm{m}), 4.21(2 \mathrm{H}, \mathrm{q}, J=7.3 \mathrm{~Hz}), 4.59$ $(1 \mathrm{H}, \mathrm{dd}, J=5.4$ and $7.8 \mathrm{~Hz}), 6.87-6.89(2 \mathrm{H}, \mathrm{m}), 6.95-6.98$ $(1 \mathrm{H}, \mathrm{m}), 7.24-7.29(2 \mathrm{H}, \mathrm{m})$.

2-Phenoxy-1-hexanol (IX)

Compound VIII was reduced to $\mathbf{I X}$ with LiAlH4 in the same manner as that described in $\mathbf{5}$. Yield $100 \%$. ${ }^{1} \mathrm{H}-\mathrm{NMR}\left(\mathrm{CDCl}_{3}\right) \quad \delta: 0.89(3 \mathrm{H}, \mathrm{t}, J=6.8 \mathrm{~Hz}), 1.32-1.43(4 \mathrm{H}$, m), $1.58-1.67(2 \mathrm{H}, \mathrm{m}), 1.70-1.77(1 \mathrm{H}, \mathrm{m}), 3.70-3.75$ (1H, m), 3.80-3.84 (1H, m), 4.32-4.37 (1H, m), 6.93-6.98 $(3 \mathrm{H}, \mathrm{m}), 7.26-7.30(2 \mathrm{H}, \mathrm{m})$.

2-Phenoxy-1-hexanal $(\mathbf{X})$

Compound $\mathbf{X}$ was oxidized to $\mathbf{X}$ using oxalyl chloride and DMSO in the same manner as that described in IV. After normal workup, chromatography of the crude product on silica gel using hexane and ethyl acetate (10:1) afforded the desired compound $\mathbf{X}$. Yield $85 \%$. ${ }^{1} \mathrm{H}-\mathrm{NMR}\left(\mathrm{CDCl}_{3}\right) \quad \delta: 0.92(3 \mathrm{H}, \mathrm{t}, J=7.3 \mathrm{~Hz}), 1.24-1.43$ $(2 \mathrm{H}, \mathrm{m}), 1.45-1.55(2 \mathrm{H}, \mathrm{m}), 1.82-1.90(2 \mathrm{H}, \mathrm{m}), 4.49(1 \mathrm{H}$, $\mathrm{dd}, J=2.0$ and $5.3 \mathrm{~Hz}), 6.86-6.88(2 \mathrm{H}, \mathrm{m}), 6.98-7.01(1 \mathrm{H}$, m), 7.26-7.31 $(2 \mathrm{H}, \mathrm{m}), 9.69(1 \mathrm{H}, \mathrm{d}, J=2.4 \mathrm{~Hz})$.

Ethyl 4-(3-phenoxy-1-heptenyl)benzoate (14)

To a suspension of $\mathrm{NaH}$ ( $60 \%$ in oil, $0.33 \mathrm{~g}, 14 \mathrm{mmol}$ ) in $20 \mathrm{ml}$ of THF at $0^{\circ} \mathrm{C}$ was added compound VII $(4.18 \mathrm{~g}$, $14 \mathrm{mmol}$ ) and the mixture was stirred for $0.5 \mathrm{hr}$ at room temperature. To the mixture was added compound $\mathbf{X}$ $(2.23 \mathrm{~g}, 12 \mathrm{mmol})$. After stirring for $12 \mathrm{hr}$ at room temperature, $30 \mathrm{ml}$ of water was added to the mixture, and the product was extracted with ethyl acetate. The ethyl acetate solution was washed with brine, dried over $\mathrm{Na}_{2} \mathrm{SO}_{4}$, and concentrated. The residue was purified by column chromatography on silica gel eluting with hexane and ethyl acetate (10:1) to give $2.42 \mathrm{~g}$ (51\%) of $\mathbf{1 4}$ which was a mixture of $E$ and $Z$ isomer. ${ }^{1} \mathrm{H}-\mathrm{NMR}\left(\mathrm{CDCl}_{3}\right) \delta$ : 0.92 ( $3 \mathrm{H}, \mathrm{t}, J=7.3 \mathrm{~Hz}), 1.39$ ( $3 \mathrm{H}, \mathrm{t}, J=6.8 \mathrm{~Hz}), 1.42-1.53$ $(4 \mathrm{H}, \mathrm{m}), 1.74-1.80(1 \mathrm{H}, \mathrm{m}), 1.85-1.90(1 \mathrm{H}, \mathrm{m}), 4.36(2 \mathrm{H}$, q, $J=6.8 \mathrm{~Hz}), 4.75-4.80(1 \mathrm{H}, \mathrm{m}), 6.36(1 \mathrm{H}, \mathrm{dd}, J=6.4$ and $16.1 \mathrm{~Hz}), 6.62(1 \mathrm{H}, \mathrm{d}, J=16.1 \mathrm{~Hz}), 6.93-6.95(3 \mathrm{H}, \mathrm{m})$, 7.24-7.29 (3H, m), $7.41(2 \mathrm{H}, \mathrm{d}, J=8.3 \mathrm{~Hz}), 7.97(2 \mathrm{H}, \mathrm{d}$, $J=8.3 \mathrm{~Hz})$.

Ethyl 4-(3-phenoxyheptyl)benzoate (15)

Compound $\mathbf{1 4}(0.9 \mathrm{~g}, 2.7 \mathrm{mmol})$ was dissolved in $10 \mathrm{ml}$ of methanol and to this solution was added a catalytic amount of palladium on carbon. The mixture was stirred for $15 \mathrm{hr}$ at room temperature in a hydrogen atmosphere. The mixture was filtered through a pad of Celite, and then concentrated. The resulting residue was purified by column chromatography on silica gel eluting with hexane and ethyl acetate (10:1) to give $\mathbf{1 5}(0.86 \mathrm{~g}$, 95\%) as a colorless oil. ${ }^{1} \mathrm{H}-\mathrm{NMR}\left(\mathrm{CDCl}_{3}\right) \delta: 0.88(3 \mathrm{H}, \mathrm{t}$, $J=7.3 \mathrm{~Hz}), 1.26-1.35(4 \mathrm{H}, \mathrm{m}), 1.39(3 \mathrm{H}, \mathrm{t}, J=7.3 \mathrm{~Hz})$, 1.60-1.73 (2H, m), 1.93-2.02 (2H, m), 2.70-2.87 (2H, m), 4.21-4.24 (1H, m), $4.36(2 \mathrm{H}, \mathrm{q}, J=7.3 \mathrm{~Hz}), 6.85-6.87$ $(2 \mathrm{H}, \mathrm{m}), 6.91-6.95(1 \mathrm{H}, \mathrm{m}), 4.21(2 \mathrm{H}, \mathrm{d}, J=8.3 \mathrm{~Hz})$, 7.24-7.29 (2H, m), $7.94(2 \mathrm{H}, \mathrm{d}, J=8.3 \mathrm{~Hz})$.

\section{2-Benzyl-1-hexanal (XI)}

Compound II was oxidized to XI using oxalyl chloride and DMSO in the same manner as that described in IV. After normal workup, chromatography of the crude product on silica gel using hexane and ethyl acetate (8:1) gave the desired compound $\mathbf{X I}$ as a yellow oil. Yield 85\%. ${ }^{1} \mathrm{H}-\mathrm{NMR}\left(\mathrm{CDCl}_{3}\right) \quad \delta: 0.87(3 \mathrm{H}, \mathrm{t}, J=6.8 \mathrm{~Hz})$, $1.23-1.38(4 \mathrm{H}, \mathrm{m}), 1.44-1.53(1 \mathrm{H}, \mathrm{m}), 1.60-1.67(1 \mathrm{H}$, $\mathrm{m}), 2.57-2.65(1 \mathrm{H}, \mathrm{m}), 2.70-2.75(1 \mathrm{H}, \mathrm{m}), 2.96-3.01$ $(1 \mathrm{H}, \mathrm{m}), 7.15-7.22(3 \mathrm{H}, \mathrm{m}), 7.26-7.30(2 \mathrm{H}, \mathrm{m}), 9.66$ $(1 \mathrm{H}, \mathrm{d}, J=2.9 \mathrm{~Hz})$.

Ethyl 4-(3-benzyl-1-heptenyl)benzoate (XII)

This compound was prepared in the same manner as compound $\mathbf{9}$ with use of compound $\mathbf{X I}$ instead of compound $\mathbf{X}$. Compound $\mathbf{X I I}$ was obtained as a mixture of $E$ and $Z$ isomer in $71 \%$ yield. ${ }^{~} \mathrm{H}-\mathrm{NMR}\left(\mathrm{CDCl}_{3}\right) \delta: 0.86(3 \mathrm{H}$, t, $J=5.9 \mathrm{~Hz}), 1.24-1.40(5 \mathrm{H}, \mathrm{m}), 1.39(3 \mathrm{H}, \mathrm{t}, J=7.3 \mathrm{~Hz}$, overlapped), $1.51-1.56(1 \mathrm{H}, \mathrm{m}), 2.45-2.68(1 \mathrm{H}, \mathrm{m})$, $2.70-2.76(2 \mathrm{H}, \mathrm{m}), 4.36(2 \mathrm{H}, \mathrm{q}, J=7.3 \mathrm{~Hz}), 6.13-6.27$ $(2 \mathrm{H}, \mathrm{m}), 7.14-7.19(2 \mathrm{H}, \mathrm{m}), 7.23-7.27$ (3H, m), 7.34 $(2 \mathrm{H}, \mathrm{d}, J=8.3 \mathrm{~Hz}), 7.95(2 \mathrm{H}, \mathrm{d}, J=8.3 \mathrm{~Hz})$.

\section{Ethyl 4-(3-benzylheptyl)benzoate (16)}

Compound XII was redued to $\mathbf{1 6}$ using palladium on carbon and hydrogen gas in the same manner as that described in 15. Yield $93 \%$. ${ }^{1} \mathrm{H}-\mathrm{NMR}\left(\mathrm{CDCl}_{3}\right) \quad \delta: 0.88$ $(3 \mathrm{H}, \mathrm{t}, J=7.3 \mathrm{~Hz}), 1.24-1.32(6 \mathrm{H}, \mathrm{m}), 1.38(3 \mathrm{H}, \mathrm{t}$, $J=7.3 \mathrm{~Hz}), 1.57-1.61(2 \mathrm{H}, \mathrm{m}), 1.67(1 \mathrm{H}, \mathrm{m}), 2.58-2.70$ $(4 \mathrm{H}, \mathrm{m}), 4.34(2 \mathrm{H}, \mathrm{q}, J=7.3 \mathrm{~Hz}), 7.12-7.20(3 \mathrm{H}, \mathrm{m}), 7.17$ $(2 \mathrm{H}, \mathrm{d}, J=8.3 \mathrm{~Hz}), 7.25-7.28(2 \mathrm{H}, \mathrm{m}), 7.93(2 \mathrm{H}, \mathrm{d}$, $J=8.3 \mathrm{~Hz}$ ).

Ethyl 4-(2-benzylhexyl)aminobenzoate (17)

A mixture of compound $\mathbf{X I}(0.59 \mathrm{~g}, 3.1 \mathrm{mmol})$, ethyl 4-aminobenzoate (0.56 g, $3.4 \mathrm{mmol}$ ) and $\mathrm{MgSO}_{4}(2 \mathrm{~g})$ in $10 \mathrm{ml}$ of ethanol was refluxed for $3 \mathrm{hr}$. After cooling, the mixture was filtered through a pad of Celite, and then concentrated. The product was extracted with ethyl acetate. The ethyl acetate solution was washed with brine, dried over $\mathrm{Na}_{2} \mathrm{SO}_{4}$, and concentrated. The obtained crude imine was reduced to $\mathbf{1 7}$ using palladium on carbon and hydrogen gas in the same manner as that described in 15. After normal workup, chromatography of the crude product on silica gel using hexane and ethyl acetate (10:1) afforded the desired compound $\mathbf{1 7}$ as a pale yellow oil in $48 \%$ yield. ${ }^{1} \mathrm{H}-\mathrm{NMR}\left(\mathrm{CDCl}_{3}\right) \quad \delta: 0.89(3 \mathrm{H}, \mathrm{t}$, $J=6.8 \mathrm{~Hz}), 1.24-1.39(6 \mathrm{H}, \mathrm{m}), 1.38(3 \mathrm{H}, \mathrm{t}, J=6.8$, overlapped), $1.93-2.04(1 \mathrm{H}, \mathrm{m}), 2.57(1 \mathrm{H}, \mathrm{dd}, J=7.8$ and 13.7 $\mathrm{Hz}), 2.74(1 \mathrm{H}, \mathrm{dd}, J=5.9$ and $13.7 \mathrm{~Hz}), 3.05-3.08(2 \mathrm{H}$, m), $4.29(1 \mathrm{H}, \mathrm{br} \mathrm{s}), 4.30(2 \mathrm{H}, \mathrm{q}, J=6.8 \mathrm{~Hz}), 6.39(2 \mathrm{H}, \mathrm{d}$, $J=8.8 \mathrm{~Hz}), 7.14-7.21(3 \mathrm{H}, \mathrm{m}), 7.26-7.31(2 \mathrm{H}, \mathrm{m}), 7.81$ $(2 \mathrm{H}, \mathrm{d}, J=8.8 \mathrm{~Hz})$. 
Ethyl 4-(2-benzylhexanamido)benzoate (18)

To a mixture of compound $\mathbf{I}(0.5 \mathrm{~g}, 2.4 \mathrm{mmol})$, ethyl 4-aminobenzoate (0.44 g, $2.7 \mathrm{mmol}$ ) and DMAP (0.03 g, $0.25 \mathrm{mmol})$ in $10 \mathrm{ml}$ of dichloromethane was added 1-[3-(dimethylamino)propyl]-3-ethylcarbodiimide hydrochloride $(0.52 \mathrm{~g}, 2.7 \mathrm{mmol})$ at $0{ }^{\circ} \mathrm{C}$. After stirring for $14 \mathrm{hr}$ at room temperature, a $2 \mathrm{M}$ aqueous solution of $\mathrm{HCl}(5 \mathrm{ml})$ was added to the mixture and the product was extracted with ethyl acetate. The ethyl acetate solution was washed with water and brine, dried over $\mathrm{Na}_{2} \mathrm{SO}_{4}$, and concentrated. The residue was purified by column chromatography on silica gel eluting with hexane and ethyl acetate (3:1) to afford $0.29 \mathrm{~g}(40 \%)$ of $\mathbf{1 8}$ as a white solid, mp 104.5-106.5 ${ }^{\circ} \mathrm{C} .{ }^{1} \mathrm{H}-\mathrm{NMR}\left(\mathrm{CDCl}_{3}\right) \delta: 0.89(3 \mathrm{H}$, $\mathrm{t}, J=7.3 \mathrm{~Hz}), 1.32-1.35$ (4H, m), $1.38(3 \mathrm{H}, \mathrm{t}, J=7.3 \mathrm{~Hz})$, 1.59-1.60 (1H, m), 1.82-1.87 (1H, m), 2.39-3.43 (1H, m), 2.81-2.86 (1H, m), 2.94-3.00 (1H, m), $4.34(2 \mathrm{H}, \mathrm{q}$, $J=7.3 \mathrm{~Hz}), 6.82-6.87(1 \mathrm{H}$, br s), $7.16-7.20$ (3H, m), 7.24-7.27 (2H, m), 7.39 ( $2 \mathrm{H}, \mathrm{d}, J=8.3 \mathrm{~Hz}), 7.95(2 \mathrm{H}, \mathrm{d}$, $J=8.3 \mathrm{~Hz})$.

\section{Biological evaluation}

Anti-JH activity (precocious metamorphosis-inducing activity)

B. mori (Shunrei $\times$ Shougetsu) larvae were reared on artificial diet as previously reported (Yoshida et al., 2000). Test compounds in acetone solution (1 4 $\mu$ //larva) were topically applied to the dorsal abdomen of $24 \mathrm{hr}-$ old 3rd instar and newly molted 4th instar larvae. Twenty larvae were used for each dose. The activity of compounds was evaluated by the induction of precocious metamorphosis: spinning a cocoon and subsequent pupation or formation of larval-pupal intermediates from the 4th instar (penultimate) larval period.

JH activity

Twenty-four hours after 3rd molt, the corpora allata were extirpated with fine forceps under a binocular microscope as described by Ohtaki et al. (1972). Test compounds in an acetone solution ( $4 \mu \mathrm{l} /$ larva) were each applied topically to the dorsal abdomen of the larvae within 1 hour after the allatectomy. JH activity was evaluated by the molting into normal 5 th instar larvae.

\section{RESULTS AND DISCUSSION}

Table 1 shows the activity of alkyl 4-(2-benzylhexyloxy)benzoates to induce precocious metamorphosis in

Table 1. Precocious metamorphosis-inducing activity of alkyl 4-(2-benzylhexyloxy)benzoates against 3rd instar larvae of $B$. mori

\begin{tabular}{|c|c|c|c|c|c|}
\hline \multirow[t]{2}{*}{ No } & \multirow[b]{2}{*}{$\mathbf{R}$} & \multicolumn{4}{|c|}{$\begin{array}{c}\text { Precocious metamorphosis } \\
\text { (\%) }\end{array}$} \\
\hline & & 1 & 10 & 40 & ( $\mu \mathrm{g} /$ larva) \\
\hline 1 & $4-\mathrm{COOC}_{2} \mathrm{H}_{5}(\mathbf{K F}-\mathbf{1 3})$ & 90 & 34 & 12 & \\
\hline 2 & $4-\mathrm{COOCH}_{3}$ & 60 & 80 & 69 & \\
\hline 3 & $4-\mathrm{COO}-n-\mathrm{C}_{3} \mathrm{H}_{7}$ & 0 & 45 & 85 & \\
\hline 4 & $4-\mathrm{COO}-i-\mathrm{C}_{3} \mathrm{H}_{7}$ & 0 & 0 & 0 & \\
\hline
\end{tabular}

the 4th larval stage of $B$. mori when applied to 24-hrold 3rd instar larvae. As previously reported (Furuta et al., 2007), treatment with $\mathrm{KF}-13$ at $1 \mu \mathrm{g}$ induced precocious pupation in $90 \%$, but the activity decreased at higher doses. The activity of the methyl ester $\mathbf{2}$ at $1 \mu \mathrm{g}$ decreased in comparison with that of $\mathrm{KF}-13$, but at higher doses of 10 and $40 \mu \mathrm{g} \mathbf{2}$ was more active than $\mathrm{KF}-13$. In contrast to $\mathrm{KF}-13$, the activity of the $n$-propyl ester $\mathbf{3}$ correlated with the applied dose. Although $\mathbf{3}$ had no activity at $1 \mu \mathrm{g}$, it showed the highest activity at $40 \mu \mathrm{g}$ among the ester series tested. A dramatic decrease in activity was observed in changing from ethyl to isopropyl ester 4. The activity was found to disappear by replacing 4-ethoxycarbonyl group with 3-ethoxycarbonyl group on the benzene ring (5), indicating the parasubstituted benzoate is essential for activity. To see whether the ester group was necessary for precocious metamorphosis-inducing activity, the amide ( 6 and $\mathbf{7}$ ), alcohol (8), oxime (9 and 10), ethyl (11) and 3,4-methylenedioxy (12) analogs were assayed for their activity (Fig. 3). None of them induced precocious metamorphosis in a dose range of $1-40 \mu \mathrm{g}$. We have already reported (Furuta et al., 2007) that conversion of the ethyl ester in $\mathrm{KF}-13$ to the corresponding benzoic acid eliminated the activity. These results indicate that the ester group on the benzene ring plays an important role for activity.

Since $\mathrm{KF}-13$ showed the highest activity among the compounds tested, the 4-ethoxycarbonylphenyl moiety was fixed in the molecule, and further modification was made by introducing some functional groups between the two benzene rings. Precocious metamorphosis-inducing activity of ethyl 4-substitued benzoates and related compounds is shown in Table 2. As previously reported (Furuta et al., 2006), the phenoxy analog $\mathbf{1 3}$ at $1 \mu \mathrm{g}$ showed lower activity than $\mathrm{KF}-13$, but its activity correlated with the applied dose to some extent. The introduction of a double bond between the two benzene rings (14) decreased the degree of the activity in comparison with that of $\mathbf{1 3}$. The 2-phenoxyheptylbenzoate $\mathbf{1 5}$ and the 2-benzylheptylbenzoate $\mathbf{1 6}$ had almost the same level of activity as $\mathbf{1 3}$.

The aniline analog $\mathbf{1 7}$, in which the oxygen atom in KF-13 was replaced with a nitrogen atom, showed much higher activity at $10 \mu \mathrm{g}$ compared with that observed for $\mathrm{KF}-13$, while the activity at $1 \mu \mathrm{g}$ was somewhat less than

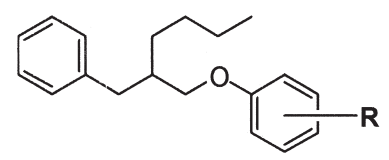
$5: \mathrm{R}=3-\mathrm{COOC}_{2} \mathrm{H}_{5}$
$9: \mathrm{R}=4-\mathrm{CH}=\mathrm{NOH}$
$6: \mathrm{R}=4-\mathrm{CONHOCH}_{3}$
$10: \mathrm{R}=4-\mathrm{CH}=\mathrm{NOCH}_{3}$
$7: \mathrm{R}=4-\mathrm{CON}\left(\mathrm{CH}_{3}\right)_{2}$
$11: \mathrm{R}=4-\mathrm{C}_{2} \mathrm{H}_{5}$
$8: \mathrm{R}=4-\mathrm{CH}_{2} \mathrm{OH}$
$12: \mathrm{R}=3,4-\mathrm{OCH}_{2} \mathrm{O}-$

Fig. 3. Structures of inactive compounds. 
Table 2. Precocious metamorphosis-inducing activity of ethyl 4-substituted benzoates and related compounds against 3rd instar larvae of $B$. mori

\begin{tabular}{|c|c|c|c|c|c|}
\hline \multirow[t]{2}{*}{ No } & \multirow[t]{2}{*}{ Compund } & \multicolumn{4}{|c|}{$\begin{array}{c}\text { Precocious metamorphosis } \\
(\%)\end{array}$} \\
\hline & & 1 & 10 & 40 & ( $\mu$ g/larva) \\
\hline 13 & & 32 & 66 & 70 & \\
\hline 14 & & 0 & 10 & 40 & \\
\hline 15 & & 45 & 65 & 79 & \\
\hline 16 & & 50 & 55 & 65 & \\
\hline 17 & & 67 & 94 & NT & \\
\hline 18 & & 0 & 0 & NT & \\
\hline 19 & & 0 & 0 & NT & \\
\hline
\end{tabular}

NT: not tested

that of $\mathrm{KF}-13$. Thus, the optimal structure for higher activity was represented by the 4-(2-benzylalkyloxy) benzoate as KF-13. The placement of an amide function between the two benzene rings (18) completely eliminated the activity. To see whether the presence of a benzene moiety was essential for activity, the isoxazolecarboxylate analog 19 was evaluated. This compound did not induce precocious metamorphosis, suggesting that the six-membered ring is favorable for activity.

On the other hand, we have recently found that $\mathrm{KF}-13$ showed clear JH activity when topically applied to allatectomized 4th instar larvae of B. mori (Fujita et al., 2008). Preliminary structure-JH activity relationship studies for ethyl 4-(2-benzylalkyloxy)benzoates exhibited that there was an apparent correlation between the ability of these compounds to cause precocious metamorphosis and their $\mathrm{JH}$ activity against allatectomized

Table 3. Effects of compounds $\mathbf{3}, \mathbf{4}, \mathbf{6}, \mathbf{1 1}, \mathbf{1 2}$ and $\mathbf{1 7}$ on the development in allatectomized 4th instar larvae of $B$. mori

\begin{tabular}{ccc}
\hline \multirow{2}{*}{ Treatment } & \multicolumn{2}{c}{ Number of larvae transformed into } \\
\cline { 2 - 3 } & Precocious pupa $\quad$ 5th instar larva \\
\hline
\end{tabular}

\begin{tabular}{ccc} 
Allatectomized & 10 & 0 \\
control & 10 & 0 \\
$\mathbf{+ 3}$ & 10 & 0 \\
$\mathbf{+ 4}$ & 10 & 0 \\
$\mathbf{+ 6}$ & 10 & 0 \\
$\mathbf{+ 1 1}$ & 10 & 0 \\
$\mathbf{+ 1 2}$ & 0 & 10 \\
$\mathbf{+ 1 7}$ & & \\
\hline
\end{tabular}

Forty mictograms of each compund in acetone solution $(4 \mu \mathrm{l})$ was topically applied to allatectomized 4 th instar larvae. Number of larvae tested: 10 4th instar larvae; KF-13, which induced precocious metamorphosis at low doses, showed much stronger JH activity than other alkyloxy analogs. We therefore examined further structure-JH activity relationship of a new series of $\mathrm{KF}-13$ analogs described in this article. Table 3 shows the JH activity of a number of compounds when topically applied to allatectomized 4th instar larvae. All of the allatectomized and acetone-treated control larvae underwent precocious metamorphosis. Compounds $\mathbf{4}, \mathbf{6}$, $\mathbf{1 1}$ and 12, which did not induce precocious metamorphosis at $1-40 \mu \mathrm{g}$, had no JH activity at $40 \mu \mathrm{g}$. The aniline analog 17, which had the highest precocious metamorphosis-inducing activity among the compounds tested in the present study, showed obvious JH activity so that all treated larvae molted into 5th instar larvae. It is noteworthy that the $n$-propyl ester $\mathbf{3}$, which induced precocious metamorphosis in a dose-dependant manner, showed no JH activity, indicating that $\mathbf{3}$ might represent a reasonable lead for the development of a genuine antiJH agent. Further studies on the structure-activity relationships of this series of compounds are in progress.

\section{ACKNOWLEDGMENTS}

This work was supported by a grant-in-aid to E. K. for scientific research (no. 17208007) from the Ministry of Education, Culture, Sports, Science, and Technology of Japan.

\section{REFERENCES}

Fujita, N., K. Furuta, H. Shirahashi, S. Hong, T. Shiotsuki and E. Kuwano 2005 Synthesis and anti-juvenile hormone activity of ethyl 4-[2-(6-methyl-3-pyridyloxy)alkyloxy]benzoates. J. Pesticide Sci., 30: 192-198

Fujita, N., K. Furuta, K. Ashibe, S. Yoshida, N. Yamada, T. Shiotsuki, M. Kiuchi and E. Kuwano 2008 Juvenile hormone activity of optically active ethyl 4-(2-benzylalkyloxy) benzoates inducing precocious metamorphosis. J. Pesticide Sci., in press

Fukuda, S. 1944 The hormonal mechanism of larval molting and metamorphosis in the silkworm. J. Fac. Sci. Tokyo Univ., 6: 477-537

Furuta, K., H. Shirahashi, H. Yamashita, K. Ashibe and E. Kuwano 2006 Synthesis and anti-juvenile hormone activity of ethyl 4-(2-aryloxyhexyl)benzoates. Biosci. Biotechnol. Biochem., 70: 746-748

Furuta, K., K. Ashibe, H. Shirahashi, N. Fujita, H. Yamashita, N. Yamada and E. Kuwano 2007 Synthesis and anti-juvenile hormone activity of ethyl 4-(2-benzylalkyloxy)benzoates and their enantiomers. J. Pesticide Sci., 32: 99-105

Kuwano, E., N. Fujita, K. Furuta and N. Yamada 2008 Synthesis and biological activity of novel anti-juvenile hormone agents. J. Pesticide Sci., 33: 14-16

Ohtaki, T., K. Kiguchi, H. Akai and K. Mori 1972 Juvenile hormone and synthetic analogues: II. Novel substances with high juvenile hormone activity. Appl. Ent. Zool., 7: 161-167

Riddiford, L. M. 1994 Cellular and molecular actions of juvenile hormone 1. General considerations and premetamorphic actions. Adv. Insect Physiol., 24: 213-274

Staal, G. B. 1986 Anti juvenile hormone agents. Ann. Rev. Entomol., 31: 391-429

Yoshida, T., T. Shiotsuki and E. Kuwano 2000 Synthesis and precocious metamorphosis-inducing activity of 3-(1-alkenyl)pyridines. J. Pesticide Sci., 25: 253-258 